\title{
Analysis on the Influential Factors of China 's Manufacturing Industry Participating in Global Value Chain
}

\author{
Ying Chen ${ }^{1, a}$ and Yonghua Yang ${ }^{2, b}$ \\ ${ }^{1}$ School of Economics and Management, Yunnan Normal University, Kunming 650500, China \\ ${ }^{2}$ School of Economics and Management, Yunnan Normal University, Kunming 650500, China \\ a2508428618@qq.com, byhyang2003@163.com
}

Keywords: Global value chain, added value, TC index, distribution of trade benefits.

\begin{abstract}
China's manufacturing industry in the global value chain in the presence of high trade surplus and low trade coexistence of the phenomenon, mainly because China is in the global value chain low-end links. In order to analyze the influencing factors of China's manufacturing industry's participation in the global value chain, this paper analyzes the competitiveness of China's manufacturing industry in the global value chain by using the TC index of trade competitiveness and then analyzes the influencing factors of China's manufacturing industry's participation in the global value industry, Finally, the regression results are analyzed and analyzed to better promote the distribution of the benefits of Chinese manufacturing industry in the global value chain.
\end{abstract}

\section{Current Situation}

China's total import and export trade from5096.5 billion US dollars in 2001 increse to 39586.44 billion US dollars in 2015, of which imports from 243.55 billion US dollars in 2001 to grow to 16820.7 billion US dollars in 2015, exports grow to \$ 22765.74 billion in 2015 from 2661 billion US dollars in 2001; The trade surplus increased year by year from \$225.5 billion in 2001 to \$5945.04 billion in 2015; Foreign exchange reserves increased from \$ 2121.65 billion in 2001 to \$ 38400 billion in 2014, 2015 had decreased.The actual use of foreign investment from 527.43 billion US dollars in 2001 increase to 1262.7 billion US dollars in 2015. Through the above data can be seen in China and the world more and more close ties, and in the international trade, China has gradually into the ranks of world development.

However, China's benefits from these trade surpluses are not much. The main reason is that China's manufacturing sector in the processing chain in the low-end value chain,With China's participation in the global value chain from low-end to high-end expansion, but also damage the high-end countries in the value chain trade interests, so that these countries will provoke a trade dispute with China, resulting in international trade friction. In order to realize China's participation in global value chain division, to enhance the value chain benefits, reduce trade disputes, avoid trade friction, to participate in the global value chain of China to study the factors that make it a better transformation of the industrial structure is imperative.

\section{Literature Review}

On the global value of the study, more and more scholars have their own point of view. Arndt (1997) argues that global value chain division of labor can enhance the international competitiveness of the final product. But if the developed countries to capital, technology-intensive products, the implementation of global value chain division of labor, it will reduce the country's profit margins and social welfare benefits. Gereffi (1999) argues that the global value chain is a global cross-enterprise network organization that involves the collection, transportation, production, sale, consumption and recycling of raw materials in order to realize the value of goods or services. Gereffi considers both the producer-driven and buyer-driven models to account for the division of the global value chain. Johnson \& Noguera $(2011,2012)$ uses the OECD-WTO International Input-Output Table data and bilateral trade data to construct a domestic value-added-to-total exports (VAX) index, which 
measures whether a country (or region) The degree of international division of labor in the value chain [1-2]. Koopman et al. \& Wang et al. (2013, 2014) builds a unified theoretical framework to measure the global value chain based on the input-output table of countries, according to the difference of the value-added sources and the final destination of the export trade. Based on the above, ) Of the total export trade of the corresponding decomposition and calculation [3-4].The above scholars have studied the global value chain from a new angle. Based on the above scholars, this paper analyzes the influencing factors of China's interest distribution under the background of China's participation in the global value chain, and analyzes the impact factors through the measurement model to analyze how to better obtain the benefits in the global value chain to sum up.

\section{The Industry and Its Influencing Factors in the Global Value Chain}

\subsection{The overall competitiveness of China's foreign trade}

China in the GVC division of labor in the process, mainly for processing trade, in the low-end part of the U-type value chain, the added value of product creation is very low, so the interest that GVC can get is very low. The Trade Competitiveness Index (TC), for example, is measured by the difference between the import and export trade of a country or region in the total amount of imports and exports. Analysis of China's participation in the context of GVC industry's competitiveness, thus judging China's position in the GVC division of labor. The specific calculation formula is as follows: $\mathrm{TC}=\left(\mathrm{E}_{\mathrm{j}}-\mathrm{I}_{\mathrm{j}}\right) /\left(\mathrm{E}_{\mathrm{j}}+\mathrm{I}_{\mathrm{j}}\right)$. Where $\mathrm{E}_{\mathrm{j}}$ and $\mathrm{I}_{\mathrm{j}}$ denote the export and import value of $\mathrm{j}$ industry (a country or a region) respectively. When $\mathrm{TC}>0$, it means that the international competitiveness is stronger; on the contrary, when TC $<0$, it means that the international competitiveness is weak. TC index indicates the level of international competitiveness of the strength.

Table 1 China's imports and exports and TC index

\begin{tabular}{|l|c|c|c|}
\hline Years & Exports & Imports & TC \\
\hline 2001 & 22024.4 & 20159.2 & 0.044 \\
\hline 2002 & 26947.9 & 24430.3 & 0.049 \\
\hline 2003 & 36287.9 & 34195.6 & 0.030 \\
\hline 2004 & 49103.3 & 46435.8 & 0.027 \\
\hline 2005 & 62648.1 & 54273.7 & 0.071 \\
\hline 2006 & 77597.2 & 63376.86 & 0.100 \\
\hline 2007 & 93563.6 & 73300.1 & 0.120 \\
\hline 2008 & 100394.9 & 79526.53 & 0.115 \\
\hline 2009 & 82029.69 & 68618.37 & 0.089 \\
\hline 2010 & 107022.8 & 94699.3 & 0.061 \\
\hline 2011 & 18983.8 & 17434.8 & 0.043 \\
\hline 2012 & 20487.1 & 18184.1 & 0.060 \\
\hline 2013 & 22090.0 & 19499.9 & 0.062 \\
\hline 2014 & 23422.9 & 19592.3 & 0.089 \\
\hline
\end{tabular}

Source: China Statistical Yearbook, and calculated by the author

Table 1 for the 2001-2014 China's imports and exports and the TC index, the table shows that China's accession to the WTO in 2001 when the TC index was 0.044 in 2007 rose to 0.120 . From 2008 after the decline, mainly by the global financial crisis, China's foreign trade has a certain negative impact. From 2011-2014 China's TC index is rising, indicating that China's foreign trade competitiveness continues to increase. 
3.2 China's Manufacturing Industry to Participate in GVC Industry Status

Table 2 China's main export manufacturing industry of TC index

\begin{tabular}{|c|c|c|c|c|c|c|c|c|c|c|c|c|c|c|}
\hline $\begin{array}{c}\text { Classification }^{\text {of goods }}{ }^{1} \\
\text { of }\end{array}$ & 2001 & 2002 & 2003 & 2004 & 2004 & 2006 & 2007 & 2008 & 2009 & 2010 & 2011 & 2012 & 2013 & 2014 \\
\hline C1 & 0.51 & 0.54 & 0.57 & 0.54 & 0.53 & 0.54 & 0.57 & 0.50 & 0.43 & 0.34 & 0.31 & 0.31 & 0.28 & 0.26 \\
\hline C2 & -0.39 & -0.43 & -0.50 & -0.60 & -0.63 & -0.70 & -0.75 & -0.75 & -0.79 & -0.82 & -0.85 & -0.86 & -0.85 & -0.84 \\
\hline C3 & -0.20 & -0.25 & -0.26 & -0.27 & -0.23 & -0.20 & -0.15 & -0.06 & -0.12 & -0.11 & -0.10 & -0.12 & -0.12 & -0.07 \\
\hline C4 & -0.35 & -0.33 & -0.33 & -0.32 & -0.25 & -0.22 & -0.20 & -0.19 & -0.24 & -0.24 & -0.17 & -0.08 & -0.04 & -0.01 \\
\hline C5 & 0.42 & 0.45 & 0.47 & 0.45 & 0.48 & 0.42 & 0.41 & 0.46 & 0.49 & 0.50 & 0.52 & 0.52 & 0.51 & 0.50 \\
\hline C6 & -0.09 & -0.08 & -0.03 & 0.07 & 0.14 & 0.21 & 0.17 & 0.17 & 0.12 & 0.00 & -0.09 & -0.03 & -0.13 & -0.17 \\
\hline C7 & -0.55 & -0.52 & -0.48 & -0.46 & -0.37 & -0.27 & -0.22 & -0.25 & -0.22 & -0.24 & -0.22 & -0.15 & -0.09 & -0.04 \\
\hline C8 & 0.51 & 0.55 & 0.58 & 0.59 & 0.64 & 0.69 & 0.73 & 0.76 & 0.76 & 0.74 & 0.73 & 0.72 & 0.74 & 0.78 \\
\hline C9 & 0.93 & 0.94 & 0.94 & 0.94 & 0.94 & 0.94 & 0.94 & 0.93 & 0.94 & 0.94 & 0.92 & 0.93 & 0.93 & 0.93 \\
\hline C10 & 0.38 & 0.45 & 0.45 & 0.48 & 0.57 & 0.60 & 0.61 & 0.65 & 0.66 & 0.61 & 0.60 & 0.62 & 0.65 & 0.67 \\
\hline C11 & -0.15 & -0.16 & -0.22 & -0.05 & -0.00 & 0.18 & 0.20 & 0.29 & -0.06 & 0.04 & 0.10 & 0.15 & 0.20 & 0.29 \\
\hline C12 & -0.06 & -0.04 & -0.01 & 0.03 & 0.09 & 0.12 & 0.16 & 0.20 & 0.19 & 0.18 & 0.18 & 0.21 & 0.22 & 0.23 \\
\hline C13 & -0.03 & -0.04 & -0.06 & 0.04 & 0.18 & 0.13 & 0.22 & 0.28 & 0.17 & 0.15 & 0.14 & 0.09 & 0.00 & -0.07 \\
\hline C14 & -0.11 & -0.20 & -0.33 & -0.37 & -0.29 & -0.26 & -0.27 & -0.25 & -0.23 & -0.24 & -0.24 & -0.19 & -0.16 & -0.15 \\
\hline
\end{tabular}

Source: China Statistical Yearbook, and calculated by the author

Table 2 mainly analyzes the main industries or sectors of GVC involved in China and the competition in the GVC division of labor. Based on the China Statistical Yearbook, this paper collects the import and export trade data of relevant industries since China joined the WTO in the past 14 years, calculates the TC index of each industry in each year, and analyzes the international situation of China's major export sectors in different sectors. Competitiveness. Through the 2001-2014 the industry's TC index can be drawn:

(1) The TC index of the industries with labor-intensive and resource-based industries such as food, tobacco, leather, textile, clothing, stone, etc. are greater than zero, indicating that these types of industries in the GVC division of labor strong competitiveness, Especially in the textile and garment industry, the TC index was 0.78 and 0.94 respectively, mainly due to China's comparative advantage compared with other developed countries, cheap labor.

(2)Technical and capital intensive industries such as machinery, electrical equipment, transportation equipment, cork products and other industries have positive and negative indicators of the TC, indicating that the competitiveness of the industry is not strong; and minerals, chemical products, rubber, plastics, Paper products and optical industries such as TC index is less than zero, indicating that the competitiveness of the industry at a disadvantage. In particular, the TC index for minerals is as low as $-\mathbf{0 . 8 4}$, and the sector is least competitive in participating in the global value chain

\subsection{Analysis of influential factors of Chinese manufacturing industry participating in GVC industry}

In the global division of value chain, the TC index analysis of the participation in GVC industry can conclude that the comparative advantages of labor and technology and capital factor endowment have a decisive influence on whether China can obtain trade benefits in GVC division of labor;Secondly, in the global division of production networks, technology as endogenous variables, will affect the stock of our And structure, thus affecting the distribution of benefits in China GVC situation;Thirdly, in the value chain production process, if the scale of the production sector is not economic, will increase the unit cost, reduce production profits, affecting China's GVC in the proportion of profit distribution, therefore, economies of scale is an important factor affecting China's participation in GVC industry;Finally, the degree of vertical specialization has an important influence

\footnotetext{
${ }^{1} \mathrm{C} 1$ : Food, beverages, alcohol, vinegar, tobacco;C2: Minerals;C3: Chemical industry and related industrial products;C4: Plastic, rubber and its products;C5: Leather, fur and its products;C6: Wood and wood products;C7: Wood pulp fiber and its products;C8: Textile materials and its products;C9: Shoes, caps and has feathers and its products;C10: Stone, cement;C11: Base metals and their products;C12: Machines, electrical equipment and spare parts;C13: Vehicles and transportation equipment;C14: Optical, camera, metrology and inspection.
} 
on how much China obtains trade benefits.In summary, the factors that influence China's participation in the global value chain industry are mainly from four aspects: comparative advantage, technological progress, economies of scale and vertical division of labor.

\section{Model Construction}

\subsection{Basic data selection and source description}

In this paper, in order to reflect the use of intermediate products in the country, using the China National Bureau of Statistics released 17 departments input-output table. In addition, in this paper, China and the developed countries as the representative of the United States as an example to study the GVC division of labor in the context of the distribution of Sino-US trade interests, in order to better measure the distribution of benefits between China and the United States, this paper in accordance with input- The classification of the classification is based on the National Bureau of Statistics submitted to the GTAP input and output table prepared by the table and its attached to the input-output table for the classification of the output sector in the table to explain.

This paper will select eight of the 17 sectors of the manufacturing sector: food manufacturing, textiles, sewing and leather manufacturing, other manufacturing, coking, gas and oil processing industry, chemical industry, machinery and equipment manufacturing, Metal products manufacturing, and other non-metallic mineral manufacturing industries. (VSS) is based on Hummel's (1999) formula, and the data are from China's input-output table. Since we only have input-output table data for 2002, 2007 and 2012, The input-output table in 2002 instead of 2001-2005, the 2007 input-output table instead of 2006-2010, the 2012 input-output table instead of 2011-2014; related industries import and export data sources The comparative advantage (RCA) is the ratio of capital to labor. The relevant data are derived from China Statistical Yearbook. The technical level (TFP) is expressed in terms of factor productivity. The data are from China Statistical Yearbook and China Statistical Yearbook. (SE) is the ratio of the main business income of the large and medium-sized enterprises in each industry to the total number of enterprises in the industry, calculated according to the relevant data of the China Statistical Yearbook. Dependent variables The trade value added (VAS) is calculated from the trade value-added method defined by Chen Hongyi (2002), which is derived from the China Statistical Yearbook and the United Nations Commodity Trade Database (UNCOMTRADE).

\subsection{Model construction and analysis}

According to the above, the establishment of model is as follows: $V A S_{i t}=\alpha+A R C A_{i t}^{b}+T F P_{i t}^{c}+V S S_{i t}^{d}+S E_{i t}^{e}+\delta$. Where: i, j, respectively, the industry and the time table subscript. VAS represents the export value of $\mathrm{i}$ industry in year t. This paper is based on the trade value-added method defined by Chen Hongyi (2002). The specific formula is as follows:

$V S^{V A}=V S^{M}-V S^{N}=\mu A^{M}\left[\left(A^{D}\right) x+\left(A^{D}\right)^{2} x+\cdots+\left(A^{D}\right)^{k} x\right]$.Among them $V S^{M}$ and $V S^{\mathbb{N}}$ refer to the vertical specialization trade volume which takes into account and does not consider the domestic industry circulation or the effect. $V S^{N}=\mu A^{M} x, V S^{M}=\mu A^{M}\left(I-A^{D}\right)^{-1} x$.VSS represents the vertical division of labor in year t. According to Hummel (1999) of the vertical division of labor specific gravity formula: $V S^{M}=\mu A^{M}\left(I-A^{D}\right)^{-1} x$.

Based on the data of China Statistical Yearbook, China Statistical Yearbook of Science and Technology and UNCOMTRADE, the author chooses the eight industries that China manufacturing industry participates in the global value chain from 2001 to 2014. According to the data of China Statistical Yearbook, China Statistical Yearbook and United Nations Commodity Trade Database (UNCOMTRADE) Using the econometric model, 
Table 3 Panel data regression results

\begin{tabular}{ccc}
\hline Independent variables & Expected symbol & Fixed-effects OLS \\
\hline Constant & + & $-0.0365(-2.76700)$ \\
RCA & + & $0.0028(2.77800) *$ \\
TFP & + & $0.3720(0.07210) * *$ \\
VSS & + & $0.4390(0.00435) * * *$ \\
SE & & $0.0530(7.30272) * *$ \\
R-squared & & 0.940 \\
Adjusted R-squared & 0.899 \\
F-statistic & $28.907 * * *$ \\
\hline
\end{tabular}

Note: $*, * *, * * *$, respectively, at $1 \%, 5 \%, 10 \%$ level significantly.

According to the results of regression analysis, found that the F statistic and t statistics were significant, the model passed the test. According to the comparison of the absolute coefficients of the independent variables, it is found that the economies of scale have the most significant influence on the trade value added of the trade. The development of economies of scale can be applied to the GVC in the four independent variables, the four independent variables are consistent with the expected symbols. The Distribution of American Trade. Vertical division of labor, technological progress, and comparative advantage also have a significant impact on the distribution of Sino-US trade interests.

\section{Conclusions}

Through the above analysis can be drawn, China's manufacturing industry in the global value chain division of labor background, China is mainly in the low-end value chain. Through the above calculation of the TC index of China's major export sectors,these labor-intensive and resource-consuming industries have low added value, so China's distribution of benefits in the GVC is also limited. In addition, by analyzing the influencing factors of China's manufacturing industry's participation in GVC industry, technological progress, comparative advantage of scale, economies of scale and vertical division of labor have had a significant impact on the distribution of benefits in the value chain. In addition, in order to improve China's global distribution of profits in the proportion of the value chain, China must be appropriate to adjust measures. Such as optimizing the structure of intensive elements of the country, cultivating professionals, improve the technical level, the introduction of advanced equipment, reduce production costs, etc., so that our labor-intensive products from the better, more technology-intensive products transition.

\section{Acknowledgments}

Corresponding author of this work is Yonghua Yang.This work is supported by Department of Science and Technology of Yunnan Province under grant number 2016FB118.

\section{References}

[1] Johnson R C, Noguera G. . Fragmentation and Trade in Value Added over Four Decades [J]. NBER Working Paper, No.18186, 2011.

[2] Johnson R C, Noguera G. . Accounting for Intermediates: Production Sharing and Trade in Value Added[J]. Journal of International Economics, 2012, 86(2) : 224-236.

[3] Koopman R, Wang Z, Wei S. . Tracing Value-Added and Double Counting in Gross Exports[J]. The American Economic Review, 2014, 104(2) : 459-494. 
[4] Wang Z, Wei S, Zhu K. . Quantifying International Production Sharing at the Bilateral and Sector Levels[J]. NBER, Working Paper, No.19677, 2013. 